\title{
Nutritional Status and Students Physical Fitness in a Junior High School of Padang
}

\author{
Riwaldi Putra*, Rosmaneli \\ Sport Education Program \\ Faculty of Sport Science \\ Padang State University \\ Padang, Indonesia \\ s2riwaldiputra@gmail.com
}

\begin{abstract}
This study aimed to determine the nutritional status and physical fitness of students Junior High School No. 15 Padang. This study was descriptive that involved 66 students. To determine the nutritional status of students using the formula $\mathrm{BMI}=$ weight $/ \mathrm{TB}^{2}$ and physical fitness using physical fitness test Indonesia (TKJI) and for data analysis is descriptive analysis $P=f / n \times 100 \%$. The nutritional status of the Junior High School Number 15 Padang students in this study of 66 samples, resulted in : very thin $6,06 \%$ (4 students), thin $18,18 \%$ (12 students), normal $59,09 \%$ (39 students), fat $13,63 \%$ ( 9 students), and obese $3,03 \%$ ( 2 students). While the result of physical fitness analysis of the students in Junior High School Number 15 Padang showed that: 6,06\% deficient (4 students), 28,78\% low (19 Students), 53,03\% medium (35 students), $12,12 \%$ well (8 students), and there are in the very well category which is $0 \%$.
\end{abstract}

Keywords - Nutritional status, level of physical fitness

\section{INTRODUCTION}

In human life, as well as for students of lower secondary education for growth and development, nutritious food and physical fitness was very needed. It's certainly to provide energy, build, and maintain body tissues and regulate life processes in the body. Now word has a meaning broader nutrition, in addition to health, nutrition someone associated with economic potential in the future, because the nutrients associated with brain development, learning, and productivity of nutrition is very important for work productivity. Nutrition was very important to be owned by the child, because nutrition both can be obtained by providing food in sufficient quantities as well as a balanced diet according to the age of each child. From the above it can be concluded that to achieve the necessary degree of optimal health and quality coverage of nutrients and stimulate brain development, optimum workability, and physical growth.

Nutritional status is an expression of a state of equilibrium in the form of specific variables or it can be said that nutritional status is an indicator of the merits of the daily food supply. "Nutritional status of signs or appearance caused by the nutrient is balance between income on one hand and on the other hand the energy expenditure which is visible through the indicator of weight and height"[1]. Assessment of nutritional status is basically a process of checking the nutritional state of a person by collecting important data both objective and subjective. Nutritional status is a condition of a person as a result of consuming and the process of the food in the body and nutrients consumed conformity with the nutrients needed by the body. Good nutritional status is required to maintain a degree of fitness and health, helping growth to a person and to support coaching achievement sportsmen.

Broadly speaking, nutrients are divided into 2 types of macronutrients and micronutrient. Macronutrient consisting of protein, fat, carbohydrates and some body needs daily amounts of micronutrients in a big number.Micronutrient consisting of vitamins and minerals. These nutrients should be sufficient and balanced.The consequence of malnourished body process depends on what nutrients are lacking. In accordance with the opinion ofthat: "Malnutrition is common (food lacks in quantity and quality) causes disturbances in the processes: 1) Growth, 2) Production of energy, 3) Defense body, 4) Structure and function brain, and 5) Conduct"[2]. Based on quote above it can be concluded that in general malnutrition can cause interference with the growth, laziness, weakness and decreased work productivity. Furthermore, malnutrition can cause decreased immune system, reduced antibody system.

Meanwhile, due to better nutrition in the body that lead to overweight or obesity. Excess energy is consumed is stored in the network in the form of fat. Obesity is a risk factor in the occurrence of many degenerative diseases such as hypertension or high blood pressure, diseases of diabetes, coronary heart disease, liver and bile sac. Therefore the nutritional state of a person who has a good nutritional status is very influential in running activities do every day, to carry out everyday activities and efforts for the development of quality human resources.

Nutritional status is the state of one's body that is caused by the ingestion, absorption and long consume of nutrients. Nutritional status is "state of the body as a result of consumption, absorption and utilization of food in the body"[3]. "Factors affecting the nutritional status of children 
were raisedincludes external factors and internal factors. External factors include 1) income, 2) education, 3) work, and 4) culture"[4].

Internal factors include 1) activity, 2) food, 3) nutrition, 4) age, 5) physical condition, and 6) infection. The examination using anthropometric measurement techniques. Measurement of body mass index (BMI) in this study using age for children aged 5-18 years. Determination of nutritional status is calculated by dividing weight in kilograms $(\mathrm{kg})$ divided by height squared in meters $(\mathrm{m})$. The formula BMI = weight $(\mathrm{kg}) / \mathrm{TB} 2(\mathrm{~m} 2)$.

Physical fitness is the ability of a person or the body's ability to perform physical activity in their daily activities in a sustainable manner without causing excessive fatigue, and still have the energy reserves to enjoy leisure and other unexpected needs. "Physical fitness is a person's ability to perform physical tasks that require durability and flexibility"[5] However according to "general physical fitness (physical fitness) is a person's ability to perform daily work efficiently without incurring excessive fatigue, to be enjoy free time"[6]. Physical fitness is the ability to complete everyday tasks with ease, "without significant fatigue and still able to enjoy their leisure time in an emergency and is still capable of doing the unexpected"[7].

In Agus mentions "physical fitness components or elements contained in the physical fitness of anyone associated with the values of health and motor skills".Physical fitness components include 1) speed, 2) Power muscular endurance, 3) explosive power, and 4) Durability of cardiovaskuler Factors that affect the physical fitness by Pate in Agus "suggests that the factors that affect a person's maximal oxygen volume is one of the size of the physical fitness level of a person such as age, sex, genetic (hereditary) and physical activity"[8].

Based on observations by the author to students in Junior High School 15 Padang, and also by teachers Sport Science Education and Helath seen students do sports activities, they looked tired like fatigue, are less enthusiastic, often sleepy during school hours and there is a face that pale, unhealthy , Researchers believe this is due to nutritional status and physical fitness level of students is still low, if it is allowed will certainly disrupt the learning process, then indirectly will affect student learning outcomes.

Based on the above, the authors are interested in doing research to prove and are looking for an overview of the nutritional status and physical fitness level of students in Junior High School 15 Padang.

\section{RESEARCH METHODOLOGY}

This study aimed to describe the Status of Nutrition and Physical Freshness students at Junior High School 15 Padang, which is housed on a football field "opel", where the field is a field that is used to study Physical Education and Recreation at Junior High School 15 Padang which was held on 15 - December 16th.

The sample in this study amounted to 66 people are charged $10 \%$ of the 660 people population using sampling techniques in Stratified Proportional Random Sampling, data in this study are primary data, nutritional status data obtained using the formula BMI (body mass index) by the "Indonesian Ministry of Health to weigh in units of $\mathrm{Kg}$ and measuring height in units of $\mathrm{M}$ with the age of children aged 5-18 years"[9].

$$
\text { Nutritional Status }=\frac{\text { Weight }(\mathrm{kg})}{T B\left(\mathrm{~m}^{2}\right)}
$$

Then the data collection techniques Physical Freshness students at Junior High School 15 Padang in Indonesia Physical Freshness test form (TKJI) which aims to measure students' ability and physical ability. TKJI test circuit consists of 5 items test items are: a) Scamper 50 meters, b) Hanging body lift, c) Baring Sitting, d) Skip upright, e) Running 1000 meters for men and $800 \mathrm{~m}$ for daughter.

This study aimed to describe the nutritional status and physical fitness of students in Junior High School 15 Padang, the numerical analysis techniques using frequency distribution techniques by the formula $\mathrm{p}=\mathrm{f} / \mathrm{nx} 100 \%$.

Table 1. Sample withdrawal

\begin{tabular}{|c|c|c|c|}
\hline \multirow{2}{*}{ Class } & \multicolumn{2}{|c|}{ Gender } & \multirow{2}{*}{ Total } \\
\cline { 2 - 4 } & Son & Daughter & \\
\hline VII & 16 & 8 & 24 \\
\hline VIII & 14 & 7 & 21 \\
\hline IX & 15 & 6 & 21 \\
\hline \multicolumn{3}{|c|}{ Total } & 66 \\
\hline
\end{tabular}

\section{RESULTS AND DISCUSSION}

From the research results of 66 samples of nutritional status of students in Junior High School 15 Padang that most of the nutritional status of male students in the category "Normal" is Very Thin $=3(6.7 \%)$, Thin $=7(15.5 \%)$, Normal $=27(60 \%)$, Fat $=7(15.5 \%)$ and Obesity $=1$ (2.3\%), then the data from 21 samples obtained by the spread of the answer is: Very thin $=1(4.8 \%)$, thin $=5$ $(23.8 \%)$, Normal $=12(57.1 \%)$, Fat $=2(9.5 \%)$ and Obesity $=1(4.8 \%)$.

The main cause of nutritional deficiency status is not income and expenditure of energy balancing. "The main cause of being overweight is the energy intake exceeds expenditure"[3]. While the main causes of underweight is an eating disorder that makes nutritional intake is reduced.

Students need to overcome the shortage and excess nutrients remember the importance of nutrition for students. Aulianaargues that "a person who has a meager nutritional status let understand and pay attention to the food that will be consumed every day and eat nutritious food"[10]. Someone with good nutritional status (normal) let maintain their nutritional status with regular exercise and remain concerned about nutrition. While someone with excess 
nutritional status (obesity) let exercising and adjust the intake of nutrients ". Then the solution so that students can meet their nutrition, the student is encouraged attention to their diet daily.

Then from 66 samples of students in Junior High School 15 Padang illustrates the physical fitness level of "Medium" in boys and "less on student daughter. Of the 45 samples representing the male student obtained the spread of answers based on the level of classification, namely: less Once $=0$ $(0 \%)$, Less $=9(20 \%)$, Average $=29(64.4 \%)$, Good $=7$ $(15.6 \%)$, Good Once $=0(0 \%)$. Then the data obtained from 21 samples of student daughter can be obtained deployment based on level of classification that is: less Once $=4(19 \%)$, less $=10(47.6 \%)$, Medium $=6(28.6 \%)$, Good $=1(4.8 \%)$ and Good Once $=0(0 \%)$.

In addition, students who have physical fitness better course is supported by good nutrition as proposed that "students who have physical fitness are less and less so are the students who are lazy or less accustomed to physical activity like play, always riding to school, as well as in teaching physical education sport and health they do not participate in sports, so the habit like habit that causes the elements and components of physical fitness they become low, as a result students are less capable or difficulty in physical activity in learning sports physical Education and health"[11]. For that students with physical fitness, good or excellent must maintain his physical freshness. While students with category should increase the intensity of exercise, and students with less and less a category for more attention to physical fitness and start get used to exercise.

According to the Ministry of Education, "a person who tends to lack of movement or hypokinetics have low physical fitness"[12]. The more we indulge physically in everyday life is getting low quality possessed physical fitness ".

\section{CONCLUSION}

Research findings nutritional status of junior high school students in Padang 15 of 66 samples showed the highest categories of "normal" 39 (59.09\%). In addition, the category of "skinny" comparatively quite a lot that is 12 people $(18.18 \%)$. So it can be inferred from measurements of nutritional status of junior high school students 15 Padang rated "normal" although still much "less".

While the results of research on the physical fitness of students Junior High School 15 Padang from 66 samples, the category of "being" occupied the first level of a total of 35 students $(53.03 \%)$. Category "less" can be as many as 19 people $(28.78 \%)$. So we can conclude the results of research on the physical fitness level of junior high school students 15 Padang rated "moderate" even though there are still many "less".

Therefore, it can be concluded that nutritional status is not a priority in improving the physical fitness of students, but the nutritional status including one of the factors affecting the level of physical fitness of students, to have a good level of physical fitness is required then the nutritional adequacy in this body. It's mean that malnutrition is a factor in improving the physical fitness of a child.

\section{REFERENCES}

[1] Arisman, "Gizi dalam Daur Kehidupan," Palembang; Direktorat Jendral Pendidikan Tinggi Departemen Pendidikan Nasional. 2002.

[2] Almatsier , Sunita, "Prinsip-prinsip Dasar Ilmu Gizi," Jakarta; PT. Gramedia Pustaka Utama. 2001

[3] Syafrizar, dkk, "Ilmu Gizi," FIK Universitas Negeri Padang;Wineka Media. 2009, pp, 35-40.

[4] Almatsier , Sunita, "Prinsip-prinsip Dasar Ilmu Gizi, ’Jakarta; PT. Gramedia Pustaka Utama. 2002

[5] Lutan, R, "Pendidikan Kebugaran Jasmani Orientasi Pembinaa Disepanjang Hayat,"Direktorat Pemberdayaan IPTEK Olahraga.Dirjen OR. Depdiknas.Jakarta;CV.Berdua Satu tujuan.2015.

[6] Irianto, D.P, "Panduan Latihan Kebugaran," Yogyakarta; Lukman Offset. 2000, pp, 88-92.

[7] Sumarjo, "Pendidikan Jasmani dan Kesehatan Olahraga". Makalah Seminar Olahraga Nasionalke II FIK UNY, Yogyakarta. 2002.

[8] Agus, Apri, “Olahraga Kebugaran Jasmani," Padang; Sukabina Press. 2012, pp 37-45.

[9] Kemenkes, "Standar Antropometri Penilaian Status GiziAnak,” Jakarta. 2010.

[10] Auliana, R, "Gizi dan Pengolahan Pangan," Yogyakarta; Adicita. 2001.

[11] Arsil,"Tes Pengukuran dan Evaluasi Penjas," Padang; UNP Press. 2010.

[12] Depdiknas, "Ketahuilah Tingkat Kesegaran Jasmani Anda," Jakarta; Pusat Pengembangan Kualitas Jasmani Depdiknas. 2005. 